DOI: https://doi.org/10.24144/2409-6857.2021.1(57).18-29

УДК 332.62(477.7):339.9

Катуніна О.C.

\title{
ЗАСТОСУВАННЯ ДИНАМІЧНОГО ФАКТОРНОГО АНАЛІЗУ ДЛЯ МОДЕЛЮВАННЯ РИНКУ ВІРТУАЛЬНИХ АКТИВІВ УКРАЇНИ
}

\begin{abstract}
У статті розглянуто методологічні положення та інструментарій прогнозного моделювання динаміки ринку віртуальних активів, проаналізовано динаміку курсу головних криптовалют в Украӥні, для обраного портфелю валют побудовано динамічні факторні моделі, щуо поєднують підходи класичного факторного аналізу та авторегресійного аналізу. 3 метою визначення прогнозних значень окремих часових рядів показників з мінімально можливою похибкою застосовано оригінальну версію динамічного факторного аналізу, яка дозволяе в ех роst прогнозі мінімізувати похибку довільно обраного показника. Динаміку обраної системи проаналізовано з позицій двох систем часових рядів показників із різним кроком за часом при використанні щоденних та усереднених за місящь даних статистики. Прогнози иін попиту $i$ споживання криптовалют знайдені при застосуванні методів інтервального і рекурсивного покрокового прогнозування.
\end{abstract}

Ключові слова: віртуальні активи, криптовалюта, часові ряді, прогнозування, динамічні економічні системи, динамічний факторний аналіз

Постановка проблеми. На сьогоднішній день цифрова економіка, що базується на використанні комп'ютерних технологій, розвиваються прискореними темпами. Серед усього різноманіття таких технологій особливе місце займають інноваційні технології у фінансовій сфері. Необхідність у надійному та захищеному інформаційному забезпеченні при проведенні різноманітних фінансових операцій привела до швидкого розвитку та широкого впровадження блокчейн-технологій, на платформі яких розробляють та запроваджують в обіг криптографічні валюти.

В даний час в Україні віртуальні активи стають суб'єктами фінансового моніторингу, цифрову валюту визнано нематеріальним активом, на національному рівні здійснюється просування та легалізація цифрових активів, зокрема використання блокчейну, децентралізованих фінансів, впроваджуються механізми токенізації активів, формується криптоіндустрія (криптообмінники, біржі), розбудовуються алгоритми їхнього обігу в операціях торгівлі в цифровому форматі, для платежів та інвестицій тощо.

Наразі стрімко розвивається ринок технологій розподіленого реєстру та анонімного обертання віртуальних активів, усталюється його нормативна база та інфраструктура. Згідно проекту закону №3637 «Про віртуальні активи», що прийнято в першому читанні в грудні 2020 p,

СКатуніна О.С. к.е.н, дои., доцент кафедри математичного моделювання та статистики ДВНЗ "Київський начіональний економічний університет ім. Вадима Гетьмана віртуальний актив забезпечує цифровий вираз вартості, $\epsilon$ нематеріальним благом та визначається як сукупність даних в електронній формі, що має вартість та існує в системі обороту віртуальних активів.

Віртуальні цифрові активи різноманітні та $\epsilon$ максимально універсальними цифровими "сутностями": фінансові (цифрова валюта, криптовалюта, токени) та нефінансові (елементи систем лояльності, бонуси, знижки та ін.); незабезпечені або забезпечені (такі, що підтверджують майнові або немайнові права); централізовані та децентралізовані; такі, що конвертуються та неконвертовані тощо.

Задачі моніторингу операцій 3 віртуальними активами, зокрема, крипторинку та прогнозування курсів $\epsilon$ актуальними для державних установ, фінансових організацій, бірж, компаній, що займаються страхуванням та кібербезпекою, постачальників послуг у сфері блокчейну (DLT), децентралізованих автономних організацій (DAO), DeFi проектів, постачальників платіжних систем, торгівельних платформ тощо.

Суттєво, що віртуальні активи, як такі, що поєднують правову, економічну, інформаційну, технологічну, ціннісну складові, найближчим часом все активніше ставатимуть об'єктами наукових досліджень, в тому числі математичного моделювання із використанням сучасних технологій Data Science/Machine Learning, Big Data. Будуватимуться моделі динаміки вартості віртуальних активів, прогнозування насиченості, активності та траєкторій руху ринку, зокрема криптовалют, відстежування параметрів обігу віртуальних 
активів, моніторингу стрімко зростаючого обсягу транзакцій, дотримання кібербезпеки.

У різних країнах світу науковці як у теоретичних дослідженнях, так і у практиці, все більшу увагу приділяють використанню криптовалют та регулюванню їхнього обігу. Однак слід відзначити, що на цей час бракує праць, предметом наукового пошуку яких $\epsilon$ моделювання тенденцій ринку криптовалют в глобальних трансформаціях.

У цій статті розглядатимуться підходи до прогнозного моделювання динаміки ринку віртуальних активів на прикладі обігу криптовалют - найбільш поширених децентралізованих конвертованих цифрових FinTech - інструментів. Зміну курсу певного портфелю криптовалют до долара США пропонується розглядати 3 точки зору динаміки системи часових рядів (ЧР). 3 моменту появи у 2009 році першої кріптовалюти - біткоїна - на фінансовому ринку станом на 1 березня 2021 року обертається 4645 криптовалют, і їх кількість продовжує зростати $[1,2]$. Незважаючи на певні коливання, курс біткоїна, який продовжує відігравати головну роль на ринку криптовалют, продовжує невпинно зростати, перевищивши на час написання статті відмітку у 50000 \$ США. Жодна 3 існуючих на цей час економікоматематичних моделей не може врахувати всі складові та аспекти розвитку світового крипторинку. Тому на практиці для можливості проведення економічного аналізу з цієї великої кількості валют на основі головних індикаторів ринку формують інвестиційні портфелі з певної кількості криптовалют. 3 десяти визначених криптовалют 3 різною часткою у загальному кошику інвестицій для скорочення часу обчислень i зручності аналізу при розгляді динаміки попиту і пропозицій було залишено п'ять криптовалют, а саме: Bitcoin (BTC), Ethereum (ETH), Bitcoin Cash $(\mathrm{BCH})$, Litecoin (LTC) i Monero. Зауважимо, що саме ці валюти мають найбільшу вартість і обсяги обороту в порівнянні з більшістю інших. Таким чином, для аналізу була сформована ЕДС, динаміку якої характеризують 10 показників попиту i пропозицій. Зміни курсів валют у такій ЕДС розглядалися на протязі десяти місяців за період 3 1 березня 2020 року по 31 жовтня 2020 року (базовий період). Зауважимо, що вибір часового проміжку в теоретичних дослідженнях загальної динаміки системи не має суттєвого значення, оскільки основні тенденції на ринку зберігаються вже протягом кількох років. Для практичного застосування статистичних даних, звісно, слід використовувати сьогоденну інформацію.

Статистичні дані обновляються щоденно, і в обраненому часовому інтервалі накопичується значна кількість точок спостережень. Внаслідок ефекту втрати пам'яті в часових рядах (ЧР) значної довжини отримати довгостроковий прогноз 3 використанням цих даних стає проблематичним. 3 практичної точки зору найбільш цікавим для інвестора $є$ отримання короткострокового прогнозу на найближчі дні, але статистичні дані показують майже щоденне різке коливання цін попиту і пропозицій. На рис. 1, 2 наведено графіки зміни цін на обрані валюти за вказаний період.

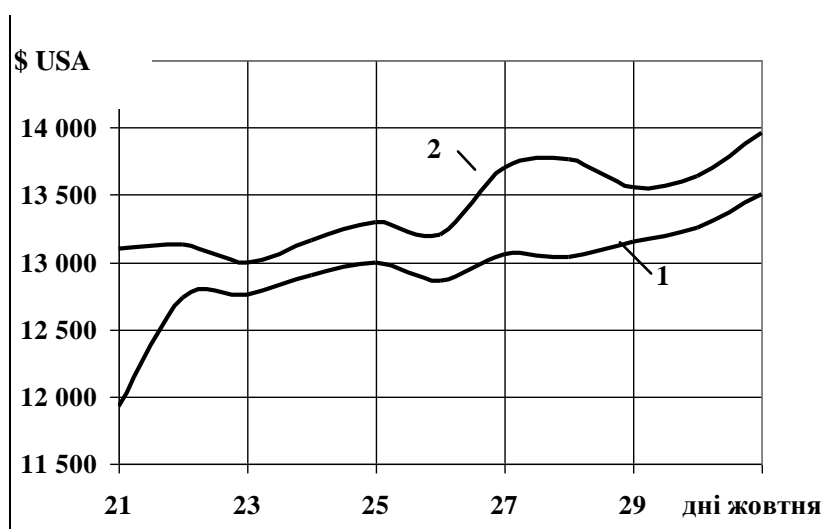

Рис. 2. Динаміка цін попиту i пропозицій біткоіна у останню декаду жовтня 2020 р: 1 - ціна попиту, 2 - ціна пропозицій
Рис. 1. Динаміка цін попиту на основні криптовалюти у базовому періоді: 1 - ETH, 2 - BTH, 3 - LTC, 4 - Monero Джерело: авторська розробка за даними [1;2].

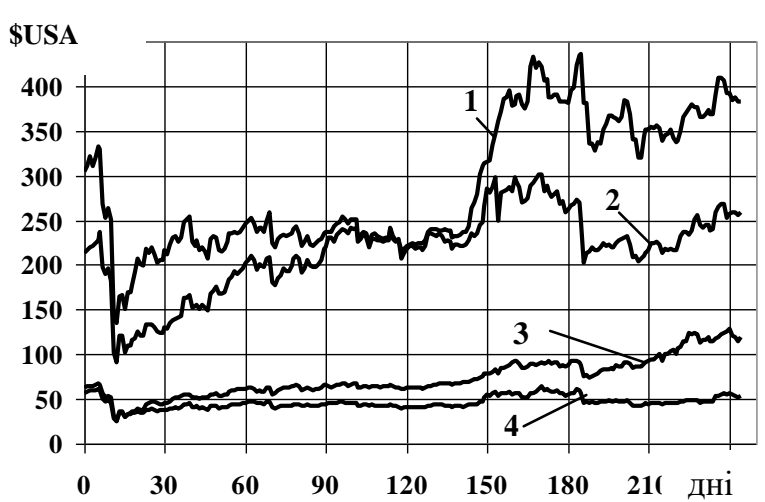


До графіків на рис. 1 не включено біткоїн, оскільки його вартість в декілька разів перевищує інші валюти, і на одній координатній сітці в однаковому масштабі їх розглядати не зручно. Для біткоїна динаміку представлено на рис.2 в зоні його найбільшого зростання у останній декаді жовтня 2020 p.

3 графіків на рис. 1 випливає, що ЧР для подальших досліджень потребують додаткової обробки відомими прийомами згладжування, але це не вирішує питання про довгостроковий прогноз. Тому для отримання уяви про еволюцію ДЕС у дещо віддаленому майбутньому в роботі пропонується розглядати системи при збільшенні кроку за часом, а для відповідних рівнів ЧР прийняти їх середні арифметичні значення за обраний новий інтервал, наприклад, тиждень або декаду спостережень. Зрозуміло, що така процедура буде дещо спотворювати істину, водночас одержуємо можливість отримати значення показників у більш віддаленому майбутньому. При цьому інтервали прогнозних значень показників можна оцінити, врахувавши дисперсію у ЧР.

3 урахуванням вказаних обставин для опису динаміки досліджуваної економічної динамічної системи (ЕДС) застосовуються динамічні факторні моделі (ДФМ), запропоновані в роботах $[3$, с. $1238-1239 ; 4$, с. $150-152 ; 5$, с. $1115-1118 ; 6$ с. 542-552], які було реалізовано в розроблених нами версіях керованого динамічного факторного аналізу (ДФА). Цей підхід ефективно використовувався при розгляді низки ЕДС, що знайшло своє відображення в публікаціях [7, с. 197-199; 8, с.; 22-24; 9, с. 9395]. Як відмічалось розробниками ДФМ, головна перевага їх використання полягає в тому, що деякі економічні зміни виявляються загальними для всієї сукупності економічних показників, що складають систему. При цьому динаміка досить великої групи спостережуваних змінних буде залежати лише від небагатьох неспостережуваних змінних - факторів. У цьому сенсі ДФМ перетинається 3 ідеологією традиційного факторного аналізу (ФА), який широко використовується в економіці та фінансах у ситуаціях, коли можна припустити, що відносно велика кількість змінних керується кількома загальними чинниками їх зміни [3, с. 1237-1238]. Це означає, що дані спостережень $n$ змінних, відображених в певній статистичній моделі, замінюються іншою моделлю, в якій кожна нова спостережувана змінна - це лінійна функція $k<n$ неспостережуваних змінних або факторів плюс залишок $e_{t}$, який визначає похибку, тобто

$$
y_{t}=A \eta_{t}+e_{t}, t=0,1,2, \ldots, T
$$

де $y_{t}, e_{t}$ - це $n \times 1$ вектори-стовпчики, $A-$ прямокутна $n \times k$ матриця і $\eta_{t}$ вектор-стовпчик $k \times 1, t-$ час, $T$ - період спостережень.

Викладені та обговорені в цитованих роботах властивості ДФМ реалізовані в оригінальному інструментарії ДФА, який $є$ поєднанням ФА i аналізу ЧР, включаючи обчислені 3 багатовимірних ЧР матриці автокореляції. Такі моделі традиційно використовувались для дослідження економічних показників, макроекономічного аналізу, ділових циклів та прогнозування. В останні роки динамічні моделі факторів стали більш популярними в емпіричній макроекономіці. Вони мають певні переваги над іншими методами в різних аспектах, і можуть, наприклад, впоратись із багатьма змінними, не вдаючись до розгляду складних проблем ступенів свободи, 3 якими часто доводиться зіштовхуватись в аналізі на основі векторної регресії.

Таким чином, застосування ДФА надає досліднику великі можливості при розгляді еволюції ДЕС різного складу. Разом 3 тим, ефективність застосованих моделей буде суттєво залежати від складу системи показників, обраного методу побудови динамічних факторів, їx кількості, тривалості лагу i, можливо, інших параметрів моделей. Ці питання потребують спеціальних досліджень і можуть бути ефективно вирішеними саме при розгляді конкретних динамічних систем.

Мета роботи полягає в обгрунтуванні використання ДФА для опису динаміки обраного портфелю криптоактивів, встановленні шляхом порівняльного аналізу загальних тенденцій зміни ï курсу i визначенні прогнозних значень показників 3 використанням розроблених раніш алгоритмів і математичного забезпечення методу керованого ДФА [7, с. 198-200; 9, с. 91-93; 10, с. 121-125].

Аналіз останніх досліджень і публікацій. Вивченню функціонування та розвитку світового ринку криптовалют присвячені численні праці зарубіжних вчених таких як В. Бауер, П. Вінья, М. Кейсі, С. Корбет, Н. Попер, К. Рогофф, М. Свон, П. Томас, Г. Хілемана, А. Фомін та інших. Інстуціональним проблемам становлення, перспективам розвитку та ризикам впровадження криптовалют приділено увагу в роботах вітчизняних вчених, зокрема, С. Аржевітіна, О. Береславської, А. Гриценка, М. Диби, Т. Єфименко, Т. Меркулової, М. Савлука, Е. Молчанової, Ю. Солодковського та інших. 
Увагу вчених привертали практичні питання пов'язані, зокрема, із можливістю та ефективністю оцінювання ступеня ризикованості інвестування у криптоактиви на підставі прогнозування їх курсової вартості, потенційного обсягу капіталізації, рівня волатильності тощо.

Моделюванню та прогнозуванню інноваційних фінансових інструментів присвячено наукові праці В. Вітлінського, Г. Данильчук, В. Галіцина, В. Геєця, П. Грицюка, I. Лук'яненко, Н. Максишко, А. Матвійчука, В. Соловйова, О.Суслова, О. Черняка та інших. Серед великої кількості публікацій слід відмітити праці Т. Желюк, О.речко [11, с. 51 - 52 ], Н. Марченка [12, с. 1-6], Л. Шірінян , Г. Роганової, А. Шірінян [13, с. 451-456], Я. Столярчука, Є. Галушка [14, с. 637 - 638], І. Лук'яненка, К. Рудь [15, с. 192-205] та інших дослідників, що внесли значний вклад $\mathrm{y}$ розвиток вітчизняного криптовалютного ринку, розробили механізм використання криптовалюти на національному ринку платежів, виявили дестабілізуючі фактори, що впливають на формування вартості біткоїну та розробили математичні моделі прогнозування динаміки цін криптовалют.

Проведений аналіз літературних джерел свідчить про те, що курсова динаміка повинна визначатися співвідношенням між попитом та пропозицією. Але питанням моделювання ринку криптовалют приділено значно менше уваги, ніж дослідженням інших фінансових інструментів, отже наразі питання щодо основних чинників, які визначають цінову політику криптовалют, лишається відкритим.

\section{Виклад основного матеріалу}

дослідження. Опис і побудова моделі ДФА докладно викладені в цитованих вище роботах. Для зручності сприйняття матеріалу зупинимося коротко на структурі розробленої моделі ДФА і особливостях ii застосування. Взагалі модель складається з трьох груп рівнянь.
Першу групу утворюють рівняння динамічних факторів

$$
F_{m}(t)=\sum_{i=1}^{N} a_{i m} y_{i}^{(m-1)}(t), \quad m=1,2, \ldots, M,
$$

які приймаються у вигляді лінійної комбінації заданих або резідуальних [9, с. 89] ЧР.

До другої групи входять динамічні рівняння факторів, кожне з яких є $A R(L)$ оцінкою $m$-го фактора

$$
\hat{F}_{m}(t)=c_{m 0}+\sum_{l=1}^{L} c_{l m} F_{m}(t-l)
$$

де $L$ - тривалість запізнення (лага), $c_{m 0}, c_{l m}$ - коефіцієнти авторегресії.

Третю групу складають рівняння лінійних регресій

$$
\hat{y}_{j}(t)=\sum_{m=1}^{M} d_{j m}^{(0)}+\sum_{m=1}^{M} d_{j m} F_{m}(t), j=1,2, \ldots, k,
$$

які виражають ЧР через динамічні фактори. Ці рівняння визначають апроксимацію вихідних ЧР $\mathrm{i}$ використовуються для їх оцінки на стадії ex-post прогнозу.

Для отримання прогнозних значень приймається допущення про динамічну інваріантність ДЕС. Це означає, що рівняння (6), (8) застосовні і в «майбутньому». Тоді, після знаходження прогнозних значень факторів за допомогою рівнянь (3) при $t>T$

$$
\hat{\hat{F}}_{m}(t)=c_{m 0}+\sum_{l=1}^{L} c_{l m} F_{m}(t-l), t>T,
$$

можна побудувати прогноз для кожного ряду. При цьому для визначення прогнозних значень окремих показників в рівняннях (4) замість факторів слід використовувати їх прогнозні значення

$$
\hat{\hat{y}}_{j}(t)=\sum_{m=1}^{M} d_{j m}^{(0)}+\sum_{m=1}^{M} d_{j m} \hat{\hat{F}}_{m}(t), t>T, j=1,2, \ldots, k,
$$

Методика знаходження параметрів моделі докладно описана в роботі [10, с. 118]. Згідно 3 нею фактори будуються послідовно один за одним, а оцінки ЧР на кожному кроці уточнюються ітеративно. Для знаходження відповідних невідомих груп коефіцієнтів $a_{i}^{(j)}$, $c_{j l}, d_{i j}$ при побудові чергового $j$-го фактору знаходиться мінімум функцій $\Phi_{j}$

$$
\Phi_{j}=w_{0}^{(j)}\left\langle F_{j}-\hat{F}_{j}, F_{j}-\hat{F}_{j}\right\rangle_{L}+\sum_{i=1}^{k} w_{i}^{(j)}\left\langle y_{i}^{(j-1)}-\hat{y}_{i}, y_{i}^{(j-1)}-\hat{y}_{i}\right\rangle
$$


за умови нормування

$$
\left\langle F_{j}, F_{j}\right\rangle=V_{j}
$$

$$
\left\langle y_{i}, y_{j}\right\rangle=\frac{1}{p-1} \sum_{s=1}^{p}\left(y_{i s}-\bar{y}_{i}\right)\left(y_{j s}-\bar{y}_{j}\right),\left\langle y_{i}, y_{j}\right\rangle_{L}=\frac{1}{p-L-1} \sum_{s=L+1}^{p}\left(y_{i s}-\bar{y}_{i}^{L}\right)\left(y_{j s}-\bar{y}_{j}^{L}\right),
$$

$w_{0}, w_{i}, V_{j}-$ додаткові додатні параметри, які отримали назву ваг і $\bar{y}_{i}=(1 / p) \sum_{s=1}^{p} y_{i s}$ арифметичні середні значення ЧР.

Розв'язок задачі нелінійного програмування (7)-(8) будується за допомогою спеціально розробленого алгоритму розв'язання задачі на умовний екстремум, який враховує алгебраїчні властивості цільової функції.

У реалізованому варіанті ДФА перший фактор будується як лінійна комбінація заданих ЧР, другий - вже як лінійна комбінація резідуальних рядів першого наближення $r_{j}^{(1)}(t)=y_{j}(t)-\hat{y}_{j}(t) . \quad$ Після $\quad$ знаходження оцінок цих рядів формується резідуальні ряди другого наближення $r_{j}^{(2)}(t)=y_{j}(t)-\hat{y}_{j}(t)-\hat{r}_{j}^{(1)}(t) . \quad$ Процедура повторюється $M$ разів, доки не буде побудовано останній фактор.

У розроблених моделях також передбачені оцінки якості прогнозу розвитку ДЕС та іiі керованість. Для знаходження прогнозних значень існує два шляхи пошуку. В першому варіанті прогноз робиться на декілька кроків вперед, так званий інтервальний прогноз. В другому варіанті, який можна назвати рекурсивним, прогноз виконується тільки на один крок вперед, тобто знаходяться значення $\hat{\hat{y}}_{i}\left(t_{n}+1\right)$. Ці значення додаються в кінець зада-них ЧР, модель будується знов, і подальший прогноз здійснються вже на основі нової моделі з розширених ЧР $y_{j}^{*}(t)=\left\{y_{j}\left(t_{1}\right), y_{j}\left(t_{2}\right), \ldots, y_{j}\left(t_{i}\right), \ldots, y_{j}\left(t_{n}\right), \hat{\hat{y}}_{j}\left(t_{n}+1\right)\right\}$

. Такий процес продовжується до кінця часового інтервала прогнозування. Зауважимо, що для отримання достатньо надійного прогнозу, довжина інтервала не повинна перевищувати 1/3 довжини заданих ЧР.

Якість розробленої моделі ДФА визначається параметрами екстремальних задач нелінійного програмування, розв'язок яких залежить від обраних значень ваг $w_{0}, w_{i}$, констант нормування $V_{m}$, довжини лагу $L$, а також від співвідношення $\eta=T_{1} / T$ між базовим i контрольним періодами в ex post прогнозі. При їх різних значеннях будемо отримувати моделі різної якості. Тому для визначення потрібних значень параметрів можна запропонувати наступну процедуру, яку можна розглядати як налагоджування моделі ДФА.

Для конкретної ДЕС обираються деякий показник, діапазони змін відповідних ваг та констант нормування, довжина лагу i обчислюються значення похибок на контрольному періоді ex post прогнозу. Після цього відповідно до обраного критерію оцінки якості прогнозу в контрольному періоді, наприклад для коефіцієнта нерівності Тейла, приймаються такі значення параметрів, для яких похибка $\epsilon$ мінімальною. Якщо в обраних діапазонах змін ваг знайдена похибка виявиться незадовільною, діапазон ваг потрібно змінити, а розрахунки повторити. Хоча фактично ця процедура зводиться до простого перебору варіантів, та у дослідника 3'являється можливість активно втручатися в процес побудови моделі.

Для визначення похибки прогнозу у дослідників не має фактичних значень показників у прогнозному періоді, а поширення на цей часовий інтервал значень похибок, знайдених в процесі ex-post прогнозу є необгрунтованим. Крім того, при первинному аналізі ДЕС визначити який iз показників найбільш суттєво впливає на динаміку всієї системи досить важко, i для знаходження параметрів моделі може призначатися довільний показник. Тоді i прогнозні значення при налаштуванні системи на мінімальну похибку різних показників i будуть відрізнятись між собою $\mathrm{i}$ для $j$-го показника утворювати деяку скінченну множину $\Omega j$. В рекурсивному процесі після першого кроку для системи $3 k$ ЧР (показників) для $j$-го показника матиме множину $\Omega_{j}=\left\{\hat{\hat{y}}_{j, 1}(T+1), \hat{\hat{y}}_{j, 2}(T+1), \ldots, \hat{\hat{y}}_{j, k}(T+1)\right\} 3 \quad k$ прогнозних значень. Система з ймовірністю $1 / k$ може розвиватися по $k$ напрямкам, i якщо врахувати всі можливі варіанти, то на наступному 
часовому кроці виникне вже $k^{2}$ прогнозних значень. Таким чином, кількість напрямків можливого розвитку динамічної системи 3 кожним наступним кроком швидко зростатиме. Тому після першого кроку для подальшого дослідження руху системи природно в якості прогнозних значень кожного показника прийняти його усереднене значення. Тоді на кожному наступному кроці буде генеруватися знов тільки $k$ варіантів. Межі довірчого інтервалу доцільно

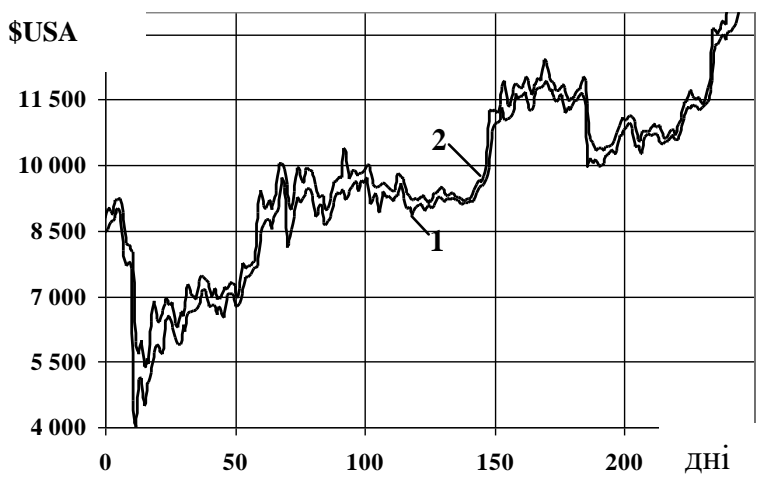

Рис. 3. Динаміка цін попиту і пропозицій біткойна у базовому періоді:

1 - ціна попиту, 2 - ціні пропозицій

Джерело: авторська розробка за даними $[1 ; 2]$.

На рис.3 приведено графіки зростання цін попиту i пропозицій для біткоїна на базовому періоді спостережень (з березня по жовтень 1921 року включно) при щоденних даних статистики, а на рис. 4 - аналогічні дані при збільшеному кроці за часом ( $\Delta t=1$ місяць), починаючи з березня

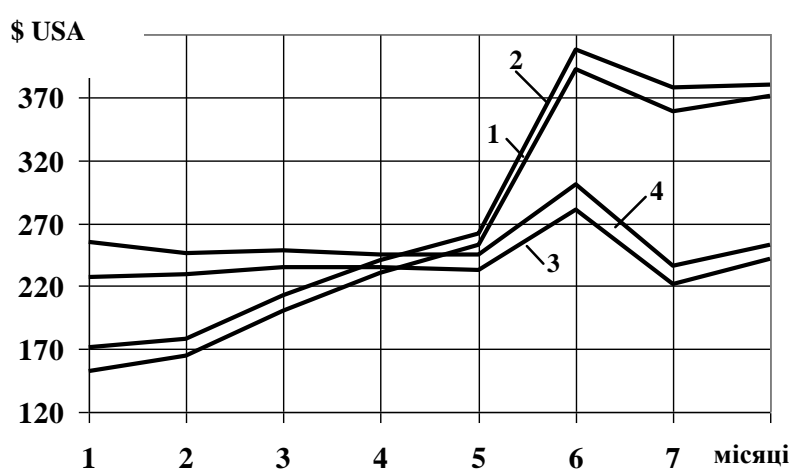

Рис. 5. Динаміка цін попиту i пропозицій криптовалют ЕТН і ВТС у базовому періоді: 1 -попит ЕТН, 2 - пропозиція ЕТН, 3 - попит ВТН, 4 - пропозиція ВТН

Джерело: авторська розробка за даними [1;2]. визначати мінімальним i максимальним значеннями знайдених прогнозів за правилом трьох сигм.

Результати досліджень. Як відзначалось вище, фактично досліджувалось фактично дві системи ЧР, які характеризують динаміку ЕДС 3 обраного портфелю валют. Спочатку розглянемо статистичні дані за базовий період спостереження. Деякі результати аналізу цих даних показані на рис. 3-6.

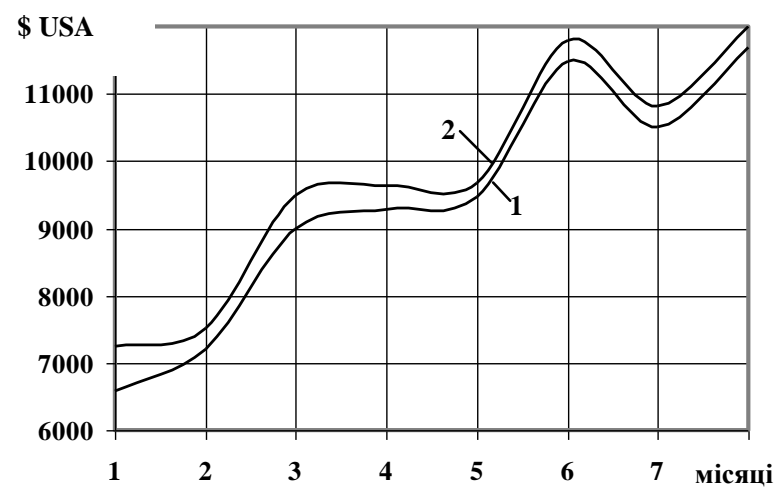

Рис. 4. Динаміка цін попиту і пропозицій біткойна у останню декаду жовтня 2020 р.: 1 - ціна попиту, 2 - ціні пропозицій

2020 року при усереднених за кожен місяць цін попиту i пропозицій. Відповідні результати 3 місячним кроком для криптовалют ЕТН і ВТС та LTC i Monero приведено на рис. 5 i pис. 6 відповідно.

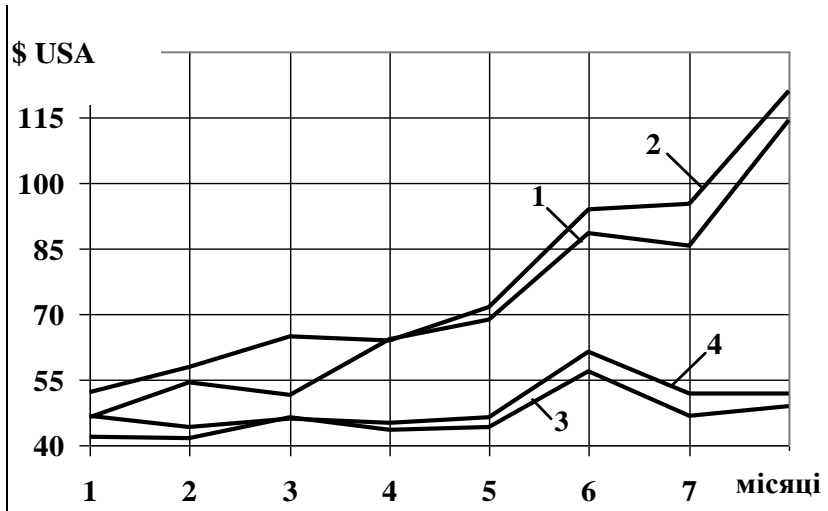

Рис. 6. Динаміка цін попиту i пропозицій криптовалют LTC і Monero у базовому періоді: 1 -попит LTC, 2 - пропозиція LTC, 3 - попит Monero, 4 - пропозиція Monero 
Узагальнюючи результати візуалізації, що представлено на рис. 1-6, результатів, можна зробити певні зауваження.

По-перше, як і слід було очікувати, графіки попиту і пропозицій майже повторюють один одного, і ціни попиту, як і повинно бути, нижче цін пропозицій. При цьому має місце деяке запізнення змін цін пропозицій після змін цін попиту.

По-друге, всі валюти мають явний максимум в серпні місяці. Для біткоїна цей максимум випадає на 170 день спостереження, а для інших валют максимуми є дещо зміщеними.

По-трете, на тлі загального зростання обох цін на всі криптовалюти, фіксується коливання курсів. Для кривих, побудованих з кроком меншої довжини за часом мають місце два типа коливань: 3 малими (кілька днів) i великими (близько місяця) періодами. Для кривих з місячним кроком спостерігається лише останній тип коливань. При цьому на різних ділянках інтервалу спостережень тривалості періодів значно відрізняються один від одного. Амплітуди коливань складають приблизно $10 \%$ від базового значення i розрізняються на різних ділянках.

Таким чином, можна стверджувати, що після різкого падіння курсу в середині березня рух цін у часі визначається двома головними складовими: монотонним підйомом і коливаннями навколо цієї траєкторії. Це добре видно з рис. 4, на якому також спостерігаються ділянки відносної стабільності: на початку інтервалу, в березні, i протягом проміжку з травня по липень включно. Це дозволяє допустити, що аналіз динаміки системи із збільшеним кроком може стати вельми корисним при аналізі динаміки ЕДС і отриманні довгострокового прогнозу.

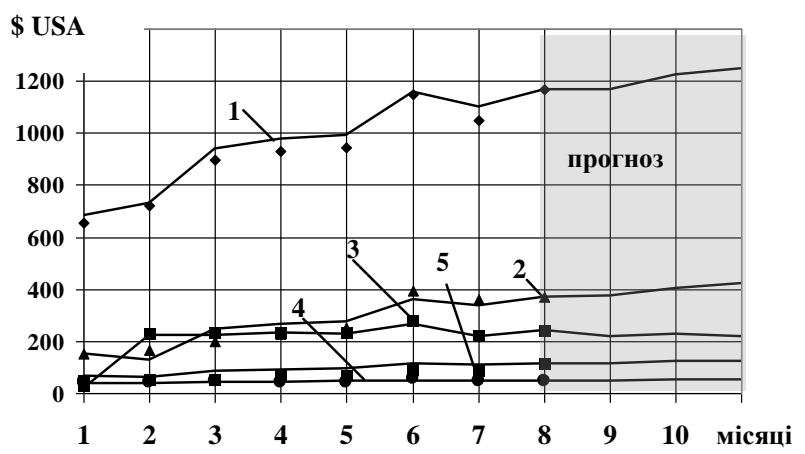

Рис. 7. Динаміка і прогноз цін попиту на кріптовалюти при щомісячному кроці
Далі на прикладах побудованих моделей ДФА для систем цін попиту і пропозицій на окремі криптовалюти проілюструємо вплив деяких параметрів моделей на якість опису динамічних станів систем і отриманих при цьому прогнозів.

Спочатку розглянемо результати, що отримано для інтервального прогнозу при аналізі ЧР 3 місячним кроком. При цьому динамічні системи для цін попиту і цін пропозицій розглядались незалежно і складалися 3 п’яти криптовалют. Оскільки, як показано при аналізі результатів спостережень, якісно динамічні зміни всіх валют $\epsilon$ схожими, фактично повторюючи одна одну, то для побудови ДФМ доцільно застосування простої схеми побудови 3 мінімізацією похибки для одного показника. Прогноз отримано на три кроки вперед, тобто до січня 1921 року включно при врахуванні двох факторів і двох одиниць запізнення. Результати розрахунків при мінімізації похибки по біткоїну для цін попиту i пропозиції наведено на рис. 7, 8 відповідно, і для зручності побудови всіх графіків на загальній координатній сітці ціни на біткоїн зменшено в 10 разів. На рисунках результати апроксимації показано суцільними лініями, а дані спостережень - відповідно маркерами.

3 наведених графіків випливає, що прості моделі, побудовані 3 використанням двох факторів, добре описують задані ЧР і здатні враховувати коливання цін, що присутні в ЧР. Розрахунки показали, що тривалість лагу майже не впливає на точність апроксимації показників в базовому часовому інтервалі. Оскільки модель налаштована на перший показник, то двофакторна модель в порівнянні 3 однофакторною краще апроксимує динаміку біткоїну, особливо в точках екстремумів,

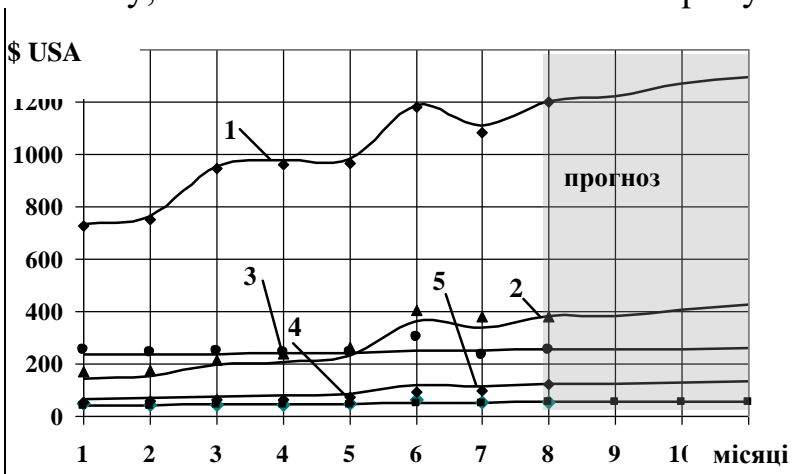

Рис. 8. Динаміка і прогноз пропозицій на кріптовалюти при щомісячному кроці

\section{1 - BTC/10, 2 - ETH, 3 - BTH, 4 - LTC, 5 - Monero}

Джерело: авторська розробка. 
i дещо погіршує апроксимацію інших валют. Зауважимо, що для оцінок можна використовувати навіть однофакторну модель, тобто фактично певний тренд.

У прогнозному інтервалі (листопад, грудень 2020 року і січень 2921 року) моделі описують монотонне зростання курсів майже всіх валют за виключенням ВТН і не передбачають коливань. При цьому визначається дещо більше зростання цін пропозицій в порівнянні 3 цінами попиту. Отримані при використанні однофакторної моделі прогнозні значення середніх цін попиту і пропозицій криптовалют представлені у табл. 1.

Прогнозні значення цін попиту і пропозицій на різні кріптовалюти при інтервальному

Таблиця 1. прогнозуванні*

\begin{tabular}{|c|c|c|c|c|c|c|}
\hline \multirow{2}{*}{ Валюта } & \multicolumn{2}{|c|}{ середні ціни пропозицій, \$ США, у } & \multicolumn{2}{|c|}{ середні ціни попиту, \$ США у } \\
\cline { 2 - 7 } & листопаді & грудні & січні & листопаді & грудні & січні \\
\hline ВТC & 12171,77 & 12706,45 & 12921,44 & 11520,66 & 11843,55 & 11937,27 \\
\hline ЕTH & 378,75 & 406,66 & 423,610 & 366,20 & 387,30 & 390,33 \\
\hline ВTH & 252,57 & 254,81 & 256,32 & 237,66 & 252,50 & 254,81 \\
\hline LTC & 51,58 & 52,90 & 53,86 & 48,90 & 49,84 & 49,97 \\
\hline Monero & 120,30 & 126,87 & 131,190 & 113,11 & 117,75 & 118,47 \\
\hline
\end{tabular}

*Джерело: авторська розробка.

Далі наведемо результати, отримані для ЕДС, що розглядається при розрахунках із кроком меншої довжини. 3 попередньо отриманих візуалізацій о зрозуміло, що часовий відрізок (остання декада жовтня 2020 р.) було обрано не зовсім вдало. Показники на цьому відрізку майже не змінюються і містять мало інформації. Тому 3 базового інтервалу було обрано відрізок у 41 день з 19 липня по 28 серпня 2020 року, на якому спостерігається інтенсивна зміна цін (рис.1). Оскільки графіки попиту і пропозицій якісно схожі, то в даному випадку у статті результати приводяться тільки для цін попиту. Параметри моделі налаштовувались на мінімізацію похибки

\$ USA

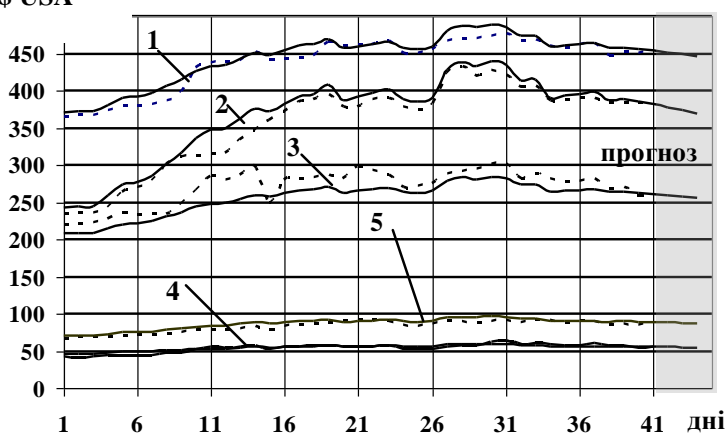

Рис. 9. Динаміка і прогноз цін попиту на кріптовалюти при щомісячному кроці за однофакторного моделюванні* для першого ряду - ціни біткоїна, і при побудові прогнозу було використано однофакторні та двофакторні моделі 3 двома одиницями запізнення.

Результати розрахунків наведено на рис. 9, 10 для однофакторної i двофакторної моделі відповідно, суцільними лініями позначені результати розрахунків, а статистичні дані пунктиром. При побудові графіків на рис. 10 значення цін на біткоїн на графіку зменшено в 20 разів. Прогнозний інтервал у 5 днів 329 серпня по 2 вересня 2020 р. відокремлено штриховою лінією і виділено кольором.

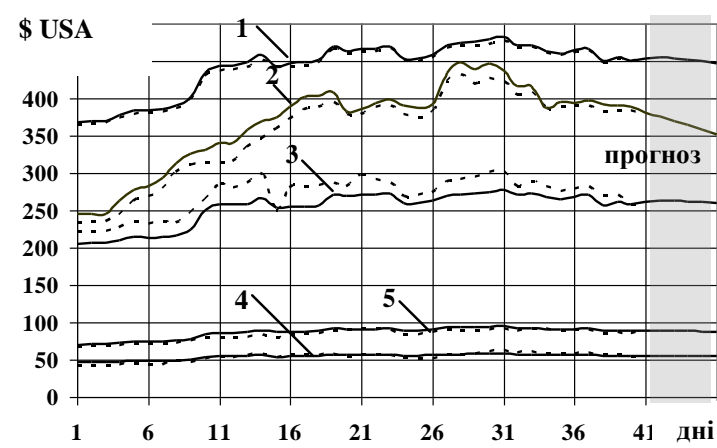

Рис. 10. Динаміка і прогноз пропозицій на кріптовалюти при щомісячному кроці за двофакторого моделювання*

\section{1 - BTC/20, 2 - ETH, 3 - BTH, 4 - LTC, 5 - Monero}


В даному випадку з’являється можливість безпосереднього порівняння отриманих прогнозних значень із статистичними даними, що і реалізовано в табл. 2. Значення відносних похибок наведено в дужках у стовпцях прогнозів.

Таблиця 2.

Інтервальні прогнози і фактичні значення цін попиту в \$ США при використанні однофакторних і двофакторних моделей*

\begin{tabular}{|c|c|c|c|c|c|c|c|c|c|c|}
\hline \multirow[b]{3}{*}{ Дата } & \\
\hline & \multicolumn{2}{|c|}{ BTC } & \multicolumn{2}{|c|}{ ETH } & \multicolumn{2}{|c|}{ ВТН } & \multicolumn{2}{|c|}{ LTC } & \multicolumn{2}{|c|}{ Monero } \\
\hline & $\begin{array}{l}\text { Фактичні } \\
\text { значення }\end{array}$ & $\begin{array}{c}\text { прогноз, } \\
\text { похибка } \\
9027.2\end{array}$ & $\begin{array}{l}\text { фактичні } \\
\text { значення }\end{array}$ & $\begin{array}{c}\text { прогноз, } \\
\text { похибка } \\
377,47\end{array}$ & $\begin{array}{l}\text { фактичні } \\
\text { значення }\end{array}$ & $\begin{array}{c}\text { прогноз, } \\
\text { похибка } \\
259,61\end{array}$ & $\begin{array}{l}\text { фактичні } \\
\text { значення }\end{array}$ & $\begin{array}{c}\text { прогноз, } \\
\text { похибка } \\
55,08,\end{array}$ & $\begin{array}{l}\text { фактичні } \\
\text { значення }\end{array}$ & $\begin{array}{c}\text { прогноз, } \\
\text { похибка } \\
88,03\end{array}$ \\
\hline 29.08 & 11476 & $(20,9 \%)$ & 395,10 & $(4.5 \%)$ & 266,23 & $(2,5 \%)$ & 56,95 & $(3,3) \%$ & 92,21 & $(4,5 \%)$ \\
\hline 30.08 & 11492 & $\begin{array}{c}8977,8 \\
(21,9 \%)\end{array}$ & 399,00 & $\begin{array}{l}373,25 \\
(5,9) \%\end{array}$ & 267,79 & $\begin{array}{l}257,98 \\
(3,4) \%\end{array}$ & 56,93 & $\begin{array}{c}54,81 \\
(3,7) \%\end{array}$ & 92,51 & $\begin{array}{c}87,49 \\
(5,4) \%\end{array}$ \\
\hline 31.08 & 11639 & $\begin{array}{c}8920,0 \\
(23,3)\end{array}$ & 423,67 & $\begin{array}{c}368,5 \\
(13,0) \%\end{array}$ & 272,96 & $\begin{array}{l}256,15 \\
(6,1) \%\end{array}$ & 60,59 & $\begin{array}{c}54,5 \\
(9,0) \%\end{array}$ & 93,03 & $\begin{array}{c}86,88 \\
(7,1) \%\end{array}$ \\
\hline 1.09 & 11616 & $\begin{array}{c}8857,2 \\
(23,8) \\
8878,4\end{array}$ & 434,06 & $\begin{array}{c}363,27 \\
(16,3) \% \\
357,47\end{array}$ & $\begin{array}{l}269,74 \\
249,70\end{array}$ & $\begin{array}{l}254,13 \\
(5,8) \% \\
251,90\end{array}$ & 59,86 & $\begin{array}{c}54,17 \\
(9,0) \% \\
53,80\end{array}$ & 91,56 & $\begin{array}{c}86,20 \\
(6,2) \% \\
85,46\end{array}$ \\
\hline 2.09 & 11334 & $(26,0 \%)$ & 436,34 & $(18,1) \%$ & & $(0,9) \%$ & 56,66 & $(5,0) \%$ & 88,02 & $(5,1) \%$ \\
\hline
\end{tabular}

3 наведених даних випливає, що застосована модель із обраними параметрами дає досить великі значення похибки прогнозних значень для двох криптовалют ВТС і ЕТН (перевищує 20\% для біткоїна), але досить добре узгоджується для інших показників. Це не узгоджується із результатами, наведеними в $[16$, с. $88-89 ; 17$, с. 202-203] для перших двох валют, і потребує пояснення. Розрахунки показали, що збільшення кількості одиниць запізнення призводить лише до незначного зменшення похибки, але прогнозування падіння курсів зберігається, що суперечить статистиці. Таке неузгодження можна пояснити можливо невдалим вибором складу ЕДС. У цитованих працях ЧР розглядалися незалежно, а в розробленій моделі розглядається система в цілому. Результати прогнозування , отримані для схожої економічної системи

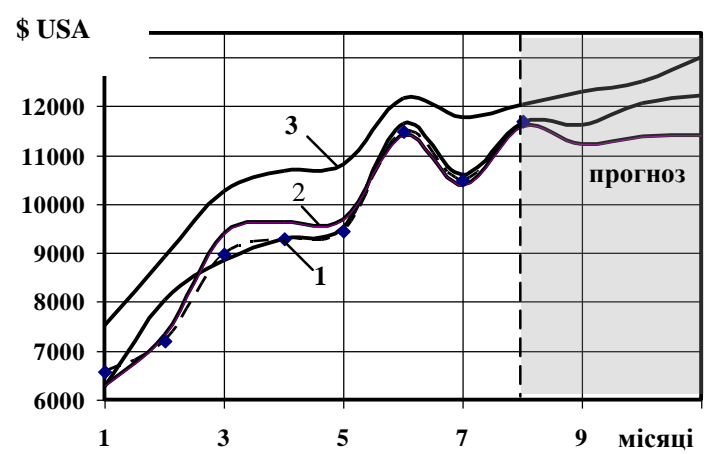

Рис. 11. Динаміка і рекурсивний прогноз цін попиту на біткойн при щомісячному кроці i різних значеннях параметрів моделі: 1 - один фактор, $\mathrm{L}=2 ; 1$ - один фактор, $\mathrm{L}=2 ; 2$ - два фактори, $\mathrm{L}=\mathbf{3}^{*}$

*Джерело: авторська розробка світових біржових індексів [7, с. 201], свідчать про високу ефективність ДФА. Можливо, таке розходження пояснюються тим, що система біржових торгів працює вже багато десятиріч, а ринок криптовалют $є$ відносно "молодим", а, отже, більш імпульсивним і таким, що не повною мірою визначається низкою стійких системних зв'язків. Ринок криптовалют тільки розвивається i на ньому можливі різні спекулятивні прояви, що і показує неузгодженість обраної ЕДС. Тому в цьому напрямку потрібні додаткові дослідження 3 метою отримання прийнятних значень похибок.

Повертаючись до щомісячного кроку на всьому проміжку спостереження, наведемо результати, що отримано при застосуванні рекурсивного прогнозування. Деякі результати розрахунків наведено на рис. 11 окремо для біткоїна, а на рис. 12 - для інших криптовалют.

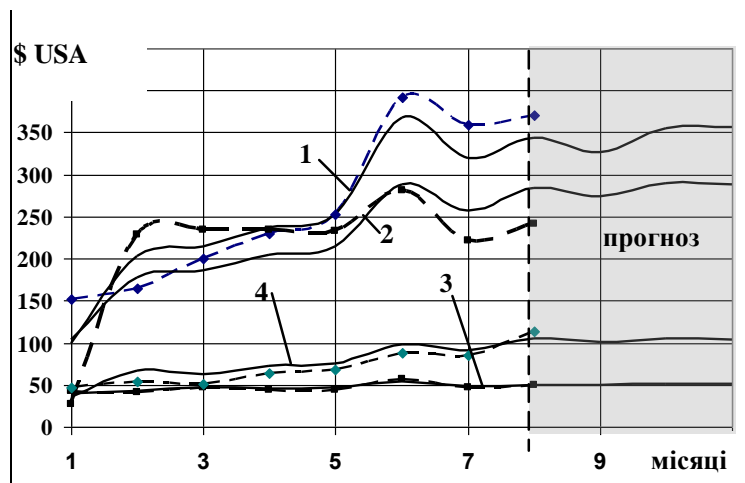

Рис. 12. Динаміка і рекурсивний прогноз цін попиту на кріптовалюти при щомісячному кроці:

1 - ETH, 2 - BTH, 3 - LTC, 4 - Monero* 
За базову була прийнята двофакторна модель 3 двома одиницями запізнення, i прогноз виконувався покроково на три кроки вперед. Зміну усереднених за місяць цін попиту на всі криптовалюти показано штриховими лініями 3 маркерами, а результати апроксимації показників і прогнозування - суцільними кривими. Оскільки рекурсивний прогноз будується покроково 3 додаванням отриманих середніх значень прогнозу до базового періоду, на рис. 11 потрапили дані після виконання прогнозу на два кроки. Також на рис. 11 графіки, що отримано для різних значень параметрів моделі (кількості факторів і одиниць запізнення), вказаних в підпису, позначено цифрами. Останнє дозволяє відслідкувати вплив зміни параметрів моделі на точність моделювання динаміки криптовалют.

3 наведених даних випливає, що двофакторна модель якісно "уловлює" коливання цін в базовому періоді 3 деякім погіршенням апроксимації в порівняні з даними рис. 7, 8, але на відміну від щоденної моделі на прогнозному інтервалі, ціни ВТС і ЕТН зростають, а для ЕТН прогнозуються коливання. За результатами візуалізації на рис. 11, визначаємо, що збільшення тривалості лагу погіршує опис базових даних, але збільшує прогнозне значення цін попиту на біткоїн. Значення останніх наведено в табл. 3 .

\section{Прогнозні значення цін попиту на крипто валюти при рекурсивному прогнозуванні*}

\begin{tabular}{cccc|c|c|c|c} 
& \multicolumn{7}{c}{ Середні місячні ціни попиту (\$ США) на кріптовалюти } \\
Місяць & \multicolumn{2}{c}{ ВТС при значеннях параметрів моделі } & ЕТН & ВТН & LTC & Monero \\
& $F=1, L=2$ & $F=2, L=2$ & $F=1, L=3$ & & & & \\
листопад. & 11607,35 & 11215,59 & 12305,18 & 326,89 & 273,73 & 49,49 & 101,44 \\
грудень & 12051,37 & 11381,39 & 12509,43 & 354,25 & 289,16 & 50,92 & 105,23 \\
січень & 12208,96 & 11404,92 & 12999,61 & 356,34 & 287,97 & 51,24 & 102,93
\end{tabular}

*Джерело: авторська розробка

Порівняння 3 результатами інтервального прогнозу (табл. 1) показує, що конкретні значення середніх цін за місяць, що отримано використаними методами, відрізняються. Розходження виявляється різним для різних прогнозних місяців і різних валют, та у середньому не перевищує декількох процентів. Найбільша різниця спостерігається для криптовалюти Monero, досягаючи 16\% для січня $1921 \mathrm{p}$.

Висновки i перспективи подальших досліджень. Викладені результати практичного дослідження із моделювання динаміки обраних криптовалют i визначення прогнозних значень цих показників, свідчать про високий прогностичний потенціал інструментарію ДФА. На відміну від існуючих методів прогнозування окремих ЧР при динамічному факторному моделюванні розглядається динаміка системи в цілому. Останне дозволяє виявити паттерни в даних динаміки, латентні внутрішні зв'язки між показниками, які проявляються при порівнянні різних моделей.

Запропонований в роботі перехід до збільшення часового кроку з усередненням даних спостережень на новому інтервалі дозволяє видалити небажані флуктуації і визначити більш загальні динамічні властивості показників. На наш погляд, розгляд однакових ЧР, але з різними кроками за часом, може виявитися вельми корисним при їх аналізі. Реалізовані в роботі методи інтервального i рекурсивного прогнозування визначають різні прогнозні значення, що може свідчити про нестійкість розвитку досліджуваної ДЕС.

Хоча в роботі отримано доволі велику похибку прогнозу, переваги моделей ДФА спонукають до продовження досліджень ринку віртуальних активів, в тому числі криптовалют шляхом вдосконалення і розробки нових моделей 3 метою досягнення прогнозних значень, які б задовольнили потенційного інвестора. Впевненість в побудові такої ефективної моделі саме на базі динамічного факторного моделювання дають результати, що було попередньо одержано автором при дослідженні інших ЕДС.

Підсумовуючи викладене відзначимо, що розробка ефективних математичних моделей динаміки ринку віртуальних активів $є$ однією 3 пріоритетних складових цифрової інфраструктури, оскільки сприяє збільшенню прозорості ринку, інформованості контрагентів, редукції невизначеності, i, як, наслідок, стимулюватиме зростання вартості віртуальних активів.

Найближчим часом розширюватиметься затребуваність розбудови екосистеми інструментів ринку віртуальних активів (систем зберігання потокових транзакційних даних, 
математичного модельного інструментарію, програмного забезпечення), зростатиме попит на цільові дослідницькі проекти, консалтингові послуги у сфері використання цифрових FinTech технологій. Центроїдом останніх мають стати аналіз та прогнозування траєкторій розвитку ринку віртуальних активів на базі визначення факторів, що зумовлюють змінення його структури та динаміки, ідентифікації паттернів поведінки ринку, визначення ситуаційних коливань, коротко- та середньострокових процесів на ньому, управління відповідними ризиками. Подальша розбудова комплексу математичних моделей, зокрема, на базі розглянутих у роботі моделей ДФА для прогнозного моніторингу ринку віртуальних активів сприятиме його детінізації та стрімкому розвитку в Україні.

\section{СПИСОК ВИКОРИСТАНИХ ДЖЕРЕЛ}

1. World Financial Market, URL: https://www.investing.com

2. Cryptocurrency Market Capitalizations, URL: http://www.coinmarketcap.com

3. Pe ̃̃ a D, Poncela P, Nonstationary dynamic factor analysis, J, of Statistical Planning and Inference, 2006. No. 136. 1237-1257.

4. Stock J,, Watson M, Macroeconomic Forecasting Using Diffusion Indexes, J, of Business and Economic Statistics. 2002. Vol.20. P: 147-162.

5. Forni M,, Lippi M, The Generalized Dynamic Factor Model: Representation Theory, Econometric Theory. 2001. Vol. 17. P: 1113-1141.

6. Forni M., Hallin M, Lippi M, Reichlin L, The generalized Dynamic Factor Model: Identification and Estimation, The Review of Economics and Statistics. 2000. Vol, 82. P. 540-554.

7. Катунина О.С. Прогнозное факторное моделирование индексов фондового рынка, Бізнес Інформ, 2017, № 11, C, 197-202.

8. Катуніна О.С. Застосування динамічних факторних моделей до аналізу макроекономіки деяких європейських та пострадянських країн: Науковий вісник Ужгородського Університету, Серія Економіка. 2019. Випуск 1 (53). С. 19-26.

9. Вітлінський В.В., Катуніна О.С. Математичне моделювання та інформаційні технології в економіці. Наукові записки Національного університету «Острозька акаде мія», серія «Економіка»: науковий журнал, Острог . № 13(41), червень. 2019. С- 89-97.

10. Катуніна О.С. Побудова динамічних факторних моделей для прогнозування розвитку економічних систем: Вісник соціально-економічних досліджень: зб, наук, праџь / За ред, : М, I, Звєрякова. 2019, № 1 (69). С, $118-127$.

11. Желюк Т,, Бречко О, Використання криптовалюти на ринку платежів: нові можливості для національних економік. Вісник Тернопільського національного економічного університету. 2016. №3, С. 50-60.

12. Марченко Н.А., Краснянська Ю.В. Реалії функціонування криптовалюти на світовому та вітчизняному ринках., Ефективна економіка. 2018. №5. - URL: http://www.economy.nayka.com.ua/pdf/5_2018/53,pdf.

13. Шірінян Л.В. Роганова Г.О. Шірінян А.С. Вплив факторів на формування вартості біткойна. Проблеми економіки. 2018. №2 (36). С. 450-458.

14. Галушка Є.О. Сутність криптовалют та перспективи їх розвитку. Молодий вчений. 2017. № 4 (44). С. 634 638.

15. Лук'яненко І.Г., Рудь К.М. Емпіричний аналіз взаємозв'язку валютного ринку та ринку криптовалют та їх реакції на дестабілізуючі фактори, Инструментальные средства моделирования систем в информационной экономике. Харків: ХНЕУ ім, С, Кузнеця. 2019. С. 191-206.

16. Дербенцев В.Д., Великоіваненко Г. І., Даценко Н. В.. Застосування методів машинного навчання до прогнозування часових рядів криптовалют. Нейро-нечіткі технологї̈ моделювання в економіці. 2019. № 8. С. 6593.

17. Даценко Н.В. Застосування дерев класифікації та регресії до прогнозування часових рядів фінансових інструментівю. Вчені записки 3б. Наукових пращъь. 2018. С. 195-206. Похибки с. 202-203.

\section{REFERENCES}

1. World Financial Market (n.d.). Retrieved from: https://www,investing,com.

2. Cryptocurrency Market Capitalizations (n.d.). Retrieved from: http://www,coinmarketcap,com. [in English].

3. Pena D., \& Poncela P. (2006). Nonstationary dynamic factor analysis, Journal of Statistical Planning and Inference, 136, 1237-1257. [in English].

4. Stock, J., \& Watson, M. (2002). Macroeconomic Forecasting Using Diffusion Indexes, Journal of Business and Economic Statistics, 20, 147-162. [in English].

5. Forni, M., \& Lippi, M. (2001). The Generalized Dynamic Factor Model: Representation Theory - Econometric Theory, 17, 1113-1141. [in English].

6. Forni, M., \& Hallin, M., \& Lippi, M., \& Reichlin, L. (2000). The generalized Dynamic Factor Model: Identification and Estimation - The Review of Economics and Statistics, 82, 540-554. [in English]. 
7. Katunina, O.S. (2017). Prognoznoye faktornoye modelirovaniye indeksov fondovogo rynka [Predictive factor modeling of stock market indices]. Business Inform, 11, 197-202. [in Russian].

8. Katunina, O.S. (2019). Zastosuvannya dynamichnykh faktornykh modeley do analizu makroekonomiky deyakykh yevropeyskykh ta postradyanskykh krayin [Application of dynamic factor models to the macroeconomic analysis of some European and post-Soviet countries] Naukovyy visnyk Uzhhorodskoho Universytetu, Seriya Ekonomika - Scientific Bulletin of Uzhhorod University, Economics Series, 1 (53), 19-26 [in Ukrainian].

9. Vitlinskyi, V. V. \& Katunina, O.S. (2019). Modelyuvannya dynamichnykh faktornykh system makroekonomichnykh pokaznykiv deyakykh krayin [Modeling of Dynamic Factor Systems of Macroeconomic Indicators of Some Countries]. Naukovi zapysky Natsionalnoho universytetu «Ostrozka akade miya», seriya «Ekonomika»: naukovyy zhurnal - Scientific notes of the National University "Ostroh Academy", series "Economics": scientific journal, 13 (41), 89- 97 [in Ukrainian].

10. Katunina, O.S. (2019). Pobudova dynamichnykh faktornykh modeley dlya prohnozuvannya rozvytku ekonomichnykh system [Construction of dynamic factor models for forecasting the development of economic systems]. Visnyk sotsialno-ekonomichnykh doslidzhen: zb, nauk, prats - Bulletin of socio-economic research: collections, sciences, works, 1 (69). 118-127 [in Ukrainian].

11. Zhelyuk, T, \& Brechko, O. (2016) Vykorystannya kryptovalyuty na rynku platezhiv: novi mozhlyvosti dlya natsionalnykh ekonomik [Use of cryptocurrency in the payments market: new opportunities for national economies]. Visnyk Ternopilskoho natsionalnoho ekonomichnoho universytetu - Bulletin of Ternopil National Economic University. 3. 50-60. [in Ukrainian].

12. Marchenko, N.A. \& Krasnyanska, Yu.B. (2018). Realiyi funktsionuvannya kryptovalyuty na svitovomu ta vitchyznyanomu rynkakh.[Realities of cryptocurrency functioning on the world and domestic markets]. Efektyvna ekonomika - Efficient economy. 5. Retrieved from: http://www,economy,nayka,com,ua/pdf/5_2018/53,pdf. [in Ukrainian].

13. Shirinyan, L.V., \& Rohanova, G.O. \& Shirinyan, A.S. (2018). Vplyv faktoriv na formuvannya vartosti bitkoyna [The influence of factors on the formation of the value of bitcoin]. Problemy ekonomiky - Problems of the economy. 2 (36). 450-458 [in Ukrainian].

14. Halushka, Ye.O. (2017). Sutnist kryptovalyut ta perspektyvy yikh rozvytku. [The essence of cryptocurrencies and prospects for their development]. Molodyy vchenyy - Young scientist. 4 (44). 634-638. [in Ukrainian].

15. Lukyanenko, I.H. \& Rud, K.M. (2019). Empirychnyy analiz vzayemozv'yazku valyutnoho rynku ta rynku kryptovalyut ta yikh reaktsiyi na destabilizuyuchi faktor. [Empirical analysis of the relationship between the foreign exchange market and the cryptocurrency market and their response to destabilizing factors]. Instrumental'nyye sredstva modelirovaniya sistem $\mathrm{v}$ informatsionnoy ekonomike - Tools for modeling systems in the information economy. 191206. [in Ukrainian].

16. Derbentsev, V.D. \&Velykoivanenko, H.I., \&Datsenko, N.V. (2019). Zastosuvannya etodiv mashynnoho navchannya do prohnozuvannya chasovykh ryadiv kryptovalyut. [Application of machine learning methods to predict time series of cryptocurrencies]. Neyro-nechitki tekhnolohiyi modelyuvannya v ekonomitsi - Neuro-fuzzy modeling technologies in economics. 8. 65-93. [in Ukrainian].

17. Datsenko, N.V. (2018). Zastosuvannya derev klasyfikatsiyi ta rehresiyi do prohnozuvannya chasovykh ryadiv finansovykh instrumentiv [Application of classification and regression trees to forecasting time series of financial instruments]. Vcheni zapysky Zb. Naukovykh prats - Bulletin of scientific works. 195-206. [in Ukrainian].

Отримано 14.03.2021 